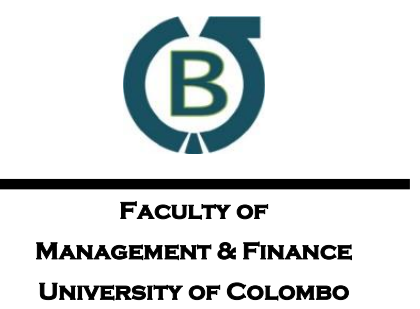

Colombo

Business

Journal

UNIVERSITY OF COLOMBO

INTERNATIONAL JOURNAL OF

THEORY \& PRACTICE

Vol. 12, No. 02, December, 2021

\title{
Conceptualising Digital Content Marketing for Greater Consumer Brand Engagement
}

\author{
Mishel Elizabeth Jacob ${ }^{\mathrm{a}} \bowtie$, Johney Johnson ${ }^{\mathrm{a}}$ \\ ${ }^{a}$ School of Management and Business Studies, Mahatma Gandhi University, India
}

\begin{abstract}
Digital Content Marketing (DCM) is the creation of valuable, relevant, and compelling content by brands, and its dissemination to their target audiences through digital platforms. In this paper, we provide a conceptual analysis of DCM and present three fundamental propositions (FPs). Underpinned by the Uses and Gratification Approach, FP1 explores six key characteristics of DCM communications (content value, relevance, reliability, consistency, interactivity, and entertainment) which can be considered as the motives for consumers to interact with them. FP2 elucidates the importance of selecting appropriate content formats (e.g., images, text-based articles, reports, videos) and content disseminating platforms (e.g., social media, websites, blogs, brand communities and discussion forums) in a DCM communication. FP3 explains the nexus between the key characteristics disseminated in different formats, through different platforms and Consumer Brand Engagement. It proposes that engagement triggered by different content formats over different platforms varies based on the gratification sought by targeted audiences.
\end{abstract}

Keywords: Digital Content Marketing, Consumer Brand Engagement, Content Value, Content Format, Digital Platforms

$\begin{array}{lll}\text { Received: } & \text { Accepted revised version: } & \text { Published: } \\ \text { 02 June 2021 } & \text { 20 November 2021 } & \text { 31 December 2021 }\end{array}$

Suggested citation: Jacob, M. E. \& Johnson, J. (2021). Conceptualising digital content marketing for greater consumer brand engagement. Colombo Business Journal, 12(2), 80102.

DOI: http://doi.org/10.4038/cbj.v12i2.83

(C2021 The Authors. This work is licensed under a Creative Commons Attribution 4.0 International License which permits unrestricted use, distribution, and reproduction in any medium, provided the original work is properly cited.

$\bowtie$ mishel.jacob@gmail.com (iD https://orcid.org/0000-0002-8256-615X 


\section{Introduction}

The term Digital Content Marketing, DCM, is a relatively new term in the marketing domain. With consumers' growing impatience with interruptive media and with their urge to seek relevant information, DCM is recognised by both practitioners and the academic community as the best alternative to build brand awareness (Holliman \& Rowley, 2014; Pulizzi, 2014; Świeczak, 2012) and customer loyalty (Forouzandeh, et al., 2014; Lou et. al. (2019), Rancati \& Gordini, 2014). DCM is the creation of content that is valuable, relevant, reliable, consistent, interactive and entertaining by brand marketers and its dissemination through digital platforms to their target audiences which include both existing and prospective customers (Hollebeek \& Macky, 2019). Unlike traditional forms of marketing communications that consumers chose to avoid, a DCM communication is often sought out by consumers (Holliman \& Rowley, 2014). For example, the beauty brand Lakme through its BeBeatiful YouTube channel provides information regarding various beauty and fashion topics. There is a very high likelihood that an individual who searches keywords such as 'make-up tutorial' or 'simple party hair style' will end up watching these branded videos. DCM is thus a revolutionary shift from the selling approach of marketing to a helping approach (Holliman \& Rowley, 2014).

The use of content marketing as a preferred tool to get through to one's existing and prospective consumers is not new (Beard et al., 2021). In the content market literature from around the world, John Deere's The Furrow magazine is often considered one of the first examples of corporate content marketing (Lieb, 2011; Pulizzi, 2014). John Deere used The Furrow magazine to educate farmers on new technologies and business opportunities in the field. Instead of overtly selling their products, John Deere became the informational expert for farmers, and when they had equipment needs, they turned to the firm. Free recipe books given to consumers by JELL-O and Milkmaid are two other prominent examples. With the advancement in digital and communication technologies, the use and significance of Content Marketing have evolved to a great extent, thereby leading to the rise of DCM. Businesses are increasingly making use of content marketing through various digital platforms; thus, it is important that they make a deliberate effort to make it effective.

Despite the heightened interest in the concept of Content Marketing in general and Digital Content Marketing in particular, very few conceptual research (e.g., Beard et al., 2021; Hollebeek \& Macky, 2019; Holliman \& Rowley, 2014; Pulizzi, 2014) or empirical research (e.g., Al-Gasawneha \& Al-Adamat, 2020; 
Human et al., 2018; Lou et al., 2019; Lou and Xie, 2020 ; Müller \& Christandl, 2019; Taiminen \& Ranaweera, 2019) have found their way into peer-reviewed literature. Even out of those, very few have tried to identify and unify the characteristics of DCM that motivate consumers to seek and interact with such content or to identify consumers' preferred digital platform or DCM content formats. Functional/ utilitarian, hedonic, authentic, and social interaction characteristics of the content have been identified as characteristics that motivate consumers to engage with DCM (Bu et al., 2020; Hollebeek \& Macky, 2019; Lou et al., 2019). However due to its singularity, one cannot argue that these alone are the characteristics of DCM and therefore further understanding of the characteristics of DCM and the method of its dissemination is warranted. Thus, identifying this gap, using Uses and Gratification theory (Herzog, 1944; McGuire 1974), we conceptualise a more comprehensive list of characteristics of DCM disseminated through different digital channels and content formats that stimulate consumers' interest in the content, and thereby, consumer brand engagement.

The paper is structured into three main sections. The first section analyses the existing literature in this field. In the second section, we develop three fundamental propositions (FPs) that conceptualise the relationships between characteristics of DCM and the dissemination of DCM content by marketers and consumer brand engagement. Finally, the paper examines the academic and managerial implications of this research. As one of the earliest studies of this kind, this paper can be a good starting point for further research on the linkage between DCM, and its consequences.

\section{Digital Marketing Content (DCM) and Customer Brand Engagement (CBE)}

One of the first studies on digital content marketing appeared in the Journal of Marketing Management in the early 2000s (Koiso-Kanttila, 2004). The author referred to digital content marketing in the context of the marketing of digital products such as news, online movies, music, games, etc., that are distributed through digital channels. In this study, Koiso-Kanttila, (2004) considered digital content as a product, with the features of both product and service, thus forming a sub-type of its own. Though the present-day definitions of DCM consider it as a value addition to the core product offered by the brand, Koiso-Kanttila's (2004) study brings out some of the essential characteristics of digital content such as customisation, interactivity, accessibility, relationship-building efforts, and an essentially zero marginal cost. 
The call for further research in DCM by Koiso-Kanttila (2004) was taken up by Rowley (2008). She defined DCM as the management process that involves "identifying, anticipating, and satisfying customer requirements profitably" (Rowley, 2008, p. 522). Content (information), in this context, is considered a part of the augmented product which helps stakeholders such as customers, retailers or other intermediaries. For example, an article on how to take beautiful pictures, on a camera brand's web page, in addition to the technical details of the camera, helps to attract and retain customers (Rowley, 2008). Today, such information is considered essential by many brands. Most cosmetics brands have their presence in video sharing networks such as YouTube with tutorials on beauty and health.

Pulizzi (2014) defines Content Marketing as "the creation of valuable, relevant and compelling content by the brand itself on a consistent basis, used to generate a positive behaviour from a customer or prospect of the brand" (p. 116). Whilst the academicians of the previous decade emphasised helping the customers, with the brand taking a back seat in the communication process, Pulizzi (2014) brought the brand into the limelight, thus paving way for the study of branded Digital Content Marketing. The intended behavioural outcome from consumers includes getting found (inbound marketing) or search engine optimization, lead generation /conversion, or leveraging social media tools (Pulizzi, 2014; Yaghtin et al., 2020). A comprehensive definition of DCM is articulated by Content Marketing Institute (2014) and further refined by Hollebeek and Macky (2019). These definitions consider content marketing as "the creation and dissemination of relevant, valuable and consistent brand-related content to current and prospective customers on digital platforms to develop their favourable brand engagement, trust, and relationships" (Hollebeek \& Macky, 2019, p. 30). Table 1 provides various definitions of DCM from extant literature.

Table 1: Definitions of DCM

\begin{tabular}{ll}
\hline Author(s) & \multicolumn{1}{c}{ Definition } \\
\hline $\begin{array}{l}\text { Koiso-Kanttila } \\
(2004, \text { p. 46) }\end{array}$ & $\begin{array}{l}\text { "Marketing of bit-based objects distributed through electronic } \\
\text { channels". }\end{array}$ \\
$\begin{array}{l}\text { Rowley (2008, p. } \\
522)\end{array}$ & $\begin{array}{l}\text { "DCM is the management process responsible for identifying, } \\
\text { anticipating, and satisfying customer requirements profitably in the } \\
\text { context of digital content, or bit-based objects distributed through } \\
\text { electronic channels". }\end{array}$ \\
& "A strategy focussed on the creation of a valuable experience". \\
Rose and Pulizzi & \\
\hline
\end{tabular}




\begin{tabular}{|c|c|}
\hline Author(s) & Definition \\
\hline $\begin{array}{l}\text { Gunelius }(2010, p \text {. } \\
\text { 14) }\end{array}$ & $\begin{array}{l}\text { "The process of indirectly and directly promoting a business or } \\
\text { brand through value-added text, video, or audio content both online } \\
\text { and offline. It can come in long-form (such as blogs, articles, e- } \\
\text { books, and so on), short-form (such as Twitter updates, Facebook } \\
\text { updates, images, and so on), or conversational-form (for example, } \\
\text { sharing great content via Twitter or participating in an active } \\
\text { discussion via blog comments or through an online forum)". }\end{array}$ \\
\hline $\begin{array}{l}\text { Bloomstein }(2012 \text {, } \\
\text { p. 101) }\end{array}$ & $\begin{array}{l}\text { "DCM is the practice of planning for the creation, delivery and } \\
\text { governance of useful, usable content" }\end{array}$ \\
\hline Pulizzi (2014, p. 5) & $\begin{array}{l}\text { "DCM is the creation of valuable, relevant and compelling content } \\
\text { by the brand itself on a consistent basis, used to generate a positive } \\
\text { behaviour from a customer or prospect of the brand". }\end{array}$ \\
\hline $\begin{array}{l}\text { Holliman and } \\
\text { Rowley }(2014, \mathrm{p} \text {. } \\
\text { 269) }\end{array}$ & $\begin{array}{l}\text { "An inbound marketing technique effected through web page, } \\
\text { social media and value-add content, and is perceived to be a useful } \\
\text { tool for achieving and sustaining trusted brand status". }\end{array}$ \\
\hline $\begin{array}{l}\text { Holliman and } \\
\text { Rowley }(2014, \mathrm{p} \text {. } \\
\text { 285) }\end{array}$ & $\begin{array}{l}\text { "DCM involves creating, distributing and sharing relevant, } \\
\text { compelling and timely digital content to engage customers at the } \\
\text { appropriate point in their buying consideration processes, such that } \\
\text { it encourages them to convert to a business building outcome". }\end{array}$ \\
\hline $\begin{array}{l}\text { Rancati and Gordini } \\
(2014, \text { p. } 96)\end{array}$ & $\begin{array}{l}\text { "A tool to share content, that creates value and high returns along } \\
\text { with the financial means of customer distribution, attraction, } \\
\text { involvement, acquisition and retention". }\end{array}$ \\
\hline $\begin{array}{l}\text { Wu and Liu }(2018 \text {, } \\
\text { p. } 750)\end{array}$ & $\begin{array}{l}\text { "It mainly refers to the production of a variety of products or brand } \\
\text { content, and the dissemination of the valuable and entertaining } \\
\text { content information on the related media platform, in order to } \\
\text { attract customers to participate in interactive communication to } \\
\text { establish and perfect brand marketing strategy". }\end{array}$ \\
\hline $\begin{array}{l}\text { Hollebeek and } \\
\text { Macky (2019, p. 26) }\end{array}$ & $\begin{array}{l}\text { "DCM is the creation and dissemination of relevant, valuable } \\
\text { brand-related content to current or prospective customers on digital } \\
\text { platforms to develop their favourable brand engagement, trust, and } \\
\text { relationships (vs. directly persuading consumers to purchase)". }\end{array}$ \\
\hline
\end{tabular}

From the definitions, we can observe the following distinctive features of DCM. Unlike the traditional marketing communication methods which are often considered interruptive (Holliman \& Rowley, 2014), content marketing is inbound marketing (Geng et al., 2020) where consumers actively seek the brands as a source of relevant, engaging, educating, or entertaining content. Unlike advertisements, customers are attracted to DCM because of the value they create for them. 
Value is what one gets in exchange for something. The use of DCM provides unique value to customers; it aids in problem-solving (Lou et al., 2019). The problem itself may present in many forms - the customer may want information (Rowley, 2008) about a particular process, phenomenon, trend, product or service or they might be looking for entertainment (Rancati \& Gordini, 2014). Many academicians opine that DCM should essentially aid consumers in their buying decision making process (Holliman \& Rowley, 2014) especially influencing the first and second stages of the buying process by raising awareness of solutions and educating consumers about a product (Steimle, 2014).

While DCM helps customers by facilitating information assimilation, learning and entertainment, it provides immense value to the firm by achieving both brandrelated (Holliman \& Rowley, 2014) and sales-related (Geng et al., 2020; Rowley, 2008) objectives. Brand related consequences of DCM include customer attraction and retention (Rancati \& Gordini, 2014), brand recognition (Rios \& Riquelme, 2010), brand awareness (Holliman \& Rowley, 2014; Pulizzi, 2014; ; Świeczak, 2012), relationship value (Taiminen \& Ranaweera, 2019), brand trust (Forouzandeh et al., 2014; Holliman \& Rowley, 2014; Rose, 2017; Wu \& Liu, 2018), and subsequently, brand loyalty (Rancati \& Gordini, 2014; Forouzandeh et al., 2014) and Brand Equity (Hutchins \& Rodriguez, 2018; Rios \& Riquelme, 2010). DCM can thus be considered an interactive long term relationship building tool (Rancati \& Gordini, 2014; Koiso-Kanttila, 2004).

For an interaction with DCM content to convert to these brand-related consequences and subsequently to purchase intention (Jacob \& Johnson, 2020) and actual purchase, it is critical that Consumer Brand Engagement (CBE) is triggered (Al-Gasawneha \& Al-Adamat, 2020; Taiminen \& Ranaweera, 2019). Target audience's CBE can be understood as the degree to which they are present - physically, emotionally, and behaviourally - while interacting with DCM (Patterson et al., 2006); i.e., how well the audience is connected, or intensity of participation in an interaction (Vivek et al., 2012). It is easier to influence the perception and behaviour of an engaged consumer as compared to one who has not paid any attention to the content (Kee \& Yazdanifard, 2015). It is often argued that engagement is essential for generating perceived value using DCM interaction (Taiminen \& Ranaweera, 2019).

In a DCM interaction, engagement can be thought of as the first level of brandrelated affect (Hollebeek \& Macky, 2019). Engagement is thus a consequence of 
consumers' interaction with the DCM contents. However, what characteristics of DCM drives consumers to interact unsolicited with DCM content is yet to be fully explored. Hollebeek and Macky (2019) propose the drivers to a DCM communication as the hedonic, functional, and authentic motives. Lou and Xie (2020) classify the three major characteristics of branded digital content as Informational Value, Social Value and Entertainment Value. However, a clear consensus is lacking amongst academicians regarding the unique characteristics of DCM. In this study, we explore some specific characteristics of the content of DCM, underpinned by the Uses and Gratification Theory (UGT, Herzog, 1944; McGuire 1974). We propose that a brand generated DCM communication is used by consumers for the gratification of their specific needs. Using existing literature, we synthesise three fundamental propositions (following the approach of Brodie et al., 2011 and Hollebeek \& Macky, 2019), that helps to understand 1) the key unique gratifications sought by consumers from a DCM interaction, which are the unique characteristics of DCM content, 2) the digital formats and digital platforms through which these interactions are sought and 3) how these characteristics, disseminated through different platforms and in different formats, trigger consumer brand engagement.

\section{Providing Key Unique Gratifications Audiences Seek Through DCM}

The main reasons for consumers to turn to a DCM is either for information or for entertainment (Lou et al., 2019). Hollebeek and Macky (2019) propose the drivers to a DCM communication as the content's hedonic, functional, and authentic characteristics. Though these motives have been used to determine consumer interaction with many traditional as well as digital forms of branded communications based on UGT (Castillo et al., 2021; Dolan et al., 2016), we believe that these alone are not the gratifications sought by consumers while interacting with DCM content. Therefore, using existing literature on DCM, the following comprehensive set of characteristics of a DCM content that encourages existing and prospective customers to interact with DCM is extracted.

\section{Valuable}

A valuable piece of content may be described as one that is informative or educational and furthers learning in customers. In general, valuable content should help its audience address a particular need or solve a specific problem (Naseri \& Noruzi, 2018). This characteristic can be understood as the content being functional, i.e., the utilitarian nature of the content. Depending on the stage in their purchase 
cycle, the consumer may be seeking information to aid them in making a buying decision or seeking information about how to use a product or even general information about a hobby or interest. Therefore, anticipating this, the marketers should create content accordingly. A corporate-sponsored travel blog, such as TripAdvisor can easily become the source of valuable information for a prospective tourist looking for places to visit in the city. Camera brands such as Canon can provide video tutorials about how to operate cameras along with photography lessons to help novice photographers through their websites and YouTube channels. This will help trigger brand awareness and help build long term relationships with the brand.

Valuable content should also have an educational or learning aspect (AlGasawneha \& Al-Adamat, 2020; Rancati \& Gordini, 2014; Pulizzi, 2014). The educational needs of each customer -existing or prospective - would be different. Often, it could be providing a deeper understanding of the product, thereby reducing the cognitive ability needed by the consumers. For example, additional productrelated information or a know-how video can reduce the shopping and decision making effort of the consumers on an online shopping site (Al-Gasawneha \& AlAdamat, 2020).

\section{Relevant}

Relevant content is what is created anticipating the target audiences' present and future needs (Naseri \& Noruzi, 2018), published in a timely manner. For prospective customers, a DCM interaction may prove to be an 'attractor' (Rowley, 2008), whereas, for existing customers, it would be a long term relationship and loyalty building tool (Rancati \& Gordini, 2014). The relevance of the content for the consumers increases their trust in the brand (Li et al., 2019).

The content should be created by marketers anticipating the customer's interest and/or needs. An example in this context is that of Mahindra's online children's store - firstcry.com. In order to provide relevant information to its target audience, i.e., parents, the firm has started their own online community at firstcry.parenting that provides a platform for parents to discuss their concerns and queries regarding their child. The site also provides relevant information regarding a variety of topics related to childbearing, pregnancy, and parenting of babies, toddlers, pre-schoolers and even teens. Unlike the internationally acclaimed pregnancy and baby communities such as BabyCenter and Pampers Village, 
Firstcry's parenting community addresses concerns culturally relevant to Indian parents (Firstcry Parenting, 2020).

Another aspect of being relevant is being timely. Content publishers should be constantly scanning the environment to align their content to the information needs of the audience at that particular period of time (Holliman \& Rowley, 2014; Pulizzi, 2014). For example, Firstcry Parenting's article during the spread of covid-19 pandemic, "how to host a virtual baby shower", was relevant and timely during that lockdown period (Wani, 2020).

\section{Reliable}

This characteristic of DCM communication relates to the content being truthful, non-biased, authentic and accurate (Naseri \& Noruzi, 2018). It is essential for consumers to be assured that the information they are seeking is coming from a credible and trustworthy source. The firm generated content often improves the perception of reliability, credibility, and trustworthiness of the information (Bruhn et al., 2012). In addition, making user generated content available increases the reliability (Müller \& Christandl, 2019). The MakeMyTrip blog provides information about a variety of travel-related topics including personal experiences by customers. For a person seeking information about a vacation, such a blog provides reliable, accurate and credible information on various aspects related to his/her travel (Kumar, 2021). Thus, it is important that the brands themselves become the most credible source of information for that niche market (Pulizzi, 2014).

\section{Consistent}

Consistency may be understood as being consistent with the brand that generates such content, i.e., a brand-content fit (Human et al., 2018), and coordinated with the brand's previously published content. It can also be understood as being authentic (Hollebeek \& Macky, 2019) and coherent (Naseri \& Noruzi, 2018). Authenticity can be understood as "what the brand truly and essentially is, and the things that the brand does/says/advertises, and how these two factors relate to each other" (Eigenraam, 2021, p. 55). For example, the DCM content provided by a sports store like Decathlon should be related to one of the various outdoor or indoor sports the store is associated with. DCM communication should have at least a peripheral relationship with the brand that publishes the material; content that are not perceived as consistent with the brand's image can backfire. Campaigns like Shell's \#MakeTheFuture, and IKEA's 'time travel experiment' were criticized for 
being inconsistent with consumers' perceived images of these brands (Eigenraam et al. 2021).

\section{Interactive}

Interactivity refers to responsiveness (Kang et. al, 2021) and the ability to easily reproduce and share the content over multiple platforms (Rowley, 2008). Interactivity also means having two-way communication or the ability to engage in information exchange with the content provider as well as other users. In the digital media context, Rowley (2008) conferred the term "Repackageability" (p. 524) to this characteristic. An article on the adventure sport, trekking, that appears in the blog of the sports store Decathlon can also be shared in their Social Networking Pages such as their Facebook page (Decathlon, 2021). The former would attract anyone who is looking for information about this sport while the latter content is directed at the existing customer base who have subscribed to the brand's fan page in social media. Being free or non-paid, thus becomes an essential feature of sharable content. This feature also distinguishes a DCM from inbound marketing communication, which is mostly targeted and permission-based to paid or existing customers (Halligan \& Shah 2010; Lusch \& Vargo 2009).

\section{Entertaining}

The characteristic of Entertainment can be understood as the hedonic value of the content. DCM is a two-directional strategy that should have both informational and entertainment objectives (Hollebeek \& Macky, 2019; Świeczak, 2012). Wu and Liu (2018) classify DCM as either being informational or interesting. However, this compartmental view of DCM characteristics is questioned by others (Hollebeek \& Macky, 2019) who argue that the reasons why consumers interact with DCM can overlap. Though facts are what customers seek, experience is what makes it memorable. Creativity is a key virtue of DCM and it is often thought of as "storytelling marketing" (Pulizzi, 2014, p.118). How much emotion a content can entice is considered a key factor in the success of a DCM communication (Kee \& Yazdanifard, 2015). Established brands like Coca-Cola have realized the importance of emotions in DCM (Pulizzi, 2017).

It is the combination of the key characteristics discussed above that attract the consumers to interact with the online content generated by a brand. Based on these key unique gratifications sought by consumers, we derive our first FP: 
$\mathrm{FP}_{1}$ : Effective DCM provides its target audience digital content that is valuable, relevant, reliable, consistent, interactive, and entertaining

\section{The Importance of DCM Content Formats and DCM Platforms}

While the content of DCM should deliver gratifications consumers seek, the effective delivery of gratification is largely dependent on its format and the platform through which the contents are delivered. Content provided by marketers can be static (image and text), dynamic (videos, user-generated content, dialogues) or a combination of these (Leung et al., 2017). The specific format of content is often dependent on the platform on which the format may be uploaded. The various formats that a DCM communication take include Blog Posts, Long Form Articles, Original Research, Video, Infographics, Images, Case Studies, White Papers/Reports, EBooks, Presentations, Webinars, Quizzes and Polls, Podcasts and Checklists (Content Marketing Institute, 2014; Järvinen \& Taiminen, 2016). With each passing year, marketers are increasing the number of tactics used to provide information and facts to the target audience (Content Marketing Institute, 2014). The capabilities of each of these formats to influence the perception of its target audience vary. For example, content in the form of images is said to be capable of drawing more consumer responses than text-only content and video content (Cvijikj\& Michahelles, 2011; Jacob, 2021; Kim et A1., 2015). However, the extent to which such generalisation is applicable in the case of a DCM environment is yet to be explored.

DCM can be disseminated through different online platforms. Corporate pages of brands in microblogs such as Twitter, and social networks such as Facebook are some of the most utilized tools for reaching customers through DCM, followed by video-sharing sites such as YouTube, Corporate-sponsored discussion forums (e.g.TripAdvisor) and corporate brand communities (e.g., BabyCenter) (Ashley \& Tuten, 2014; Brodie et al., 2011). Other platforms such as brand-sponsored blogs (e.g., Nykaa beauty book), brand's websites (e.g., Decathlon), e-newsletters (e.g., Zerodha's monthly newsletters to customers) are also used for providing content to the target audience (Taiminen \& Ranaweera, 2019). The selection of DCM platforms often depends on the target audience (Al-Gasawneha \& Al-Adamat, 2020) and the perception of the platform in the mind of the target audience. Social media-based content could be beautiful, attractive, and funny, while content in an email newsletter is often perceived as being newsworthy. While providing DCM content through a customer learning repository such as the brand's Website or blog page may stimulate customer learning, brand-sponsored communities, social media 
pages and chatrooms can trigger knowledge sharing among customers (Behnam et al., 2021). Further, brand websites, blogs, and other social media such as SNS (Social Networking Sites) like Twitter, Facebook or Instagram or Video-sharing (V$\mathrm{S})$ sites such as YouTube can be used in B2C marketing, whereas e-mails are considered an effective channel in B2B marketing (Taiminen \& Ranaweera, 2019).

Thus, content marketing achieves its optimal performance when these channels are effectively combined together (Geng et al., 2020). Therefore, we propose the second fundamental proposition of this paper:

$\mathrm{FP}_{2}$ : $\mathrm{DCM}$ content disseminated in different content formats through appropriate digital platforms/channels elicit the required responses from the target audience

\section{Triggering Consumer Brand Engagement with DCM Interaction}

When gratifying content is presented through different formats and appropriate platforms, marketers can expect the target audiences to respond positively by engaging with the content in multiple ways. Target audiences' engagement can be understood as to how present they are - physically, emotionally, and behaviorally while interacting with DCM (Patterson et al., 2006); i.e., how well the audience is connected, or the intensity of participation in an interaction (Vivek et. al., 2012).

Consumer brand engagement can be considered as a psychological process comprising cognitive and emotional aspects, which leads to behavioural outcomes. It is a multi-dimensional construct with cognitive, affective (emotional) and behavioural (activation) engagement (Hollebeek et al., 2014). The cognitive dimension is defined as "a consumer's level of brand-related thought processing and elaboration in a particular consumer/brand interaction" (Hollebeek et al., 2014, p. 154). The emotional or affective dimension refers to "a consumer's degree of positive brand-related affect in a particular consumer/brand interaction" (Hollebeek et al., 2014, p. 154). Behavioural dimension, also referred to as activation (Hollebeek et al., 2014), is defined as "a consumer's level of energy, effort and time spent on a brand in a particular consumer/brand interaction" (p. 154). Thus, Behavioural engagement can be understood as specific customer activity types or patterns (Van Doorn et al., 2010). One of the most accepted views on engagement as given by Brodie et al. (2011) is "the level of a customer's motivational, brand-related and context-dependent state of mind characterized by specific levels of cognitive, emotional and behavioural activity in brand 
interactions" (p.256). Thus, in a DCM interaction, engagement can be thought of as the customer's brand-related affect, be it behavioural, emotional, or cognitive. Emotional engagement is known to be a predictor of customer loyalty (Barari et al., 2020; Islam et al., 2018) and behavioural engagement directly and emotional engagement indirectly influence a firm's profitability.

A successful DCM interaction would be able to trigger consumer brand engagement (Taiminen \& Ranaweera, 2019). The type of engagement triggered with the different characteristics of the content (as given in FP 1) through the different platforms and in different formats (FP2) is likely to vary. In general, compared to off-line (Barari et al., 2020) and in-person interaction (Wang et al., 2019), engagement activities through digital platforms can generate more engagement from the audience. However, what type of gratification is sought by consumers while interacting with such media is still inconclusive. Some studies have found that the content's functional elements, which are the content's value, relevance, and reliability characteristics, generate a stronger attitudinal engagement formation as compared to behavioural engagement (Ashley \& Tuten, 2014; Barari et al., 2020; Wang \& McCarthy, 2020). The content's informational value and content entertainment characteristics can lead to higher engagement behaviour such as electronic word-of-mouth communication $(\mathrm{eWoM})(\mathrm{Bu}$ et al., 2020). Repeated interaction with the stimuli, which the customer perceives as reliable leads to higher emotional engagement (Rather et al., 2021). Engagement is also greatly influenced by the interactivity of the content (Busalim et al., 2020; Kang et al., 2021).

Selecting the appropriate content formats and DCM platforms for content delivery also influence consumer engagement. Existing research on the influence of content format on the level of engagement provides conflicting findings. While some research suggest that higher behavioural engagement is triggered by video format and images stimulate attitudinal engagement (Connell et al., 2019), others suggest that it is the content in image format that trigger higher behavioural engagement (Cvijikj \& Michahelles, 2011; Kim et al., 2015). The level of engagement also varies with content disseminating platforms. Whereas social networking sites such as Instagram and Facebook are likely to generate more behavioural engagement (Brodie et al., 2013; Bu et al., 2020; Connell et al., 2019; Cvijikj \& Michahelles, 2011), DCM content distributed through websites (Shin \& Back, 2019), e-mail newsletters (Taiminen \& Ranaweera, 2019) and brand communities (Brodie et al., 2013) are more likely to generate cognitive or attitudinal engagement. 
The above discussion indicates that valuable, relevant, reliable, consistent, interactive, and entertaining DCM content that is delivered by the brand through appropriate channels and in appropriate formats is capable of triggering consumer brand engagement. Thus, we derive our third Fundamental Proposition:

$\mathrm{FP}_{3}$ : Appropriately delivered, gratifying $\mathrm{DCM}$ content is capable of triggering positive target audience engagement

\section{Implications, Limitations and Directions for Future Research}

The research generates important implications for both managers and academicians. From a managerial perspective, the developed fundamental propositions indicate what existing and prospective consumers are looking for during a DCM interaction. The paper identifies key drivers that attract the target audience of DCM communication. This would help marketers in developing appropriate content for their consumers. By providing the consumers with the information/ content that they are searching for in digital spaces, DCM has the potential to become a relationship marketing tool (Vollero \& Palazzo, 2015). With DCM, managers have the flexibility to adapt to the specific gratifications sought by their customers (FP 1) in a timely manner. Capitalising on the different formats of content and different platforms available for their dissemination (FP 2), managers can easily integrate DCM strategies into the brand's overall Marketing Strategies (Wang et al., 2019). With an optimised presence in the digital space (FP 2), the firm can give consumers an opportunity to choose the content that suit their personal needs. The significance of the creation of appropriate digital content and its dissemination through the appropriate channels is what ensures the reach of DCM to its target audience. Unlike more traditional forms of marketing communication, DCM emphasises the importance of reaching prospective customers also (Hollebeek \& Macky, 2019), thus becoming an effective targeting strategy.

Managers should aim to provide content with varying characteristics (as given in FP 1) depending on the specific needs of its target audience. At the same time, it is important that the content is consistent with the brand's perceived image in the minds of customers. Presently, social media including Social Networking Sites and Video Sharing Sites are considered the most effective way to engage customers (Kilgour et al., 2015). However, considering the dynamism of the digital space, Managers should continuously assess the effectiveness of various digital platforms for the dissemination of DCM content. 
Due to its interactive two-way communication model, DCM can often help managers to elicit information from the customers. This in turn provides value to both firm and customers by getting transformed into a useful feedback system, which helps firms improve products and services (Seyyedamiri \& Tajrobehkar, 2021). However, it is important that managers provide consistent and timely content in a continuous manner to realize all the benefits of DCM. It is often the repeated interactions (compared to one-time interaction) with the brand's DCM content (Lou et al., 2019; Rather et. al., 2021) that lead to consumer brand engagement and other brand-related consequences such as brand awareness, attitude formation, brand loyalty and brand equity.

This research also brings out the importance of DCM in triggering different forms of engagement (FP 3). Activity-based behavioural engagement does not always warrant brand based outcomes (Taiminen \& Ranaweera, 2019). From a managerial perspective, this implies that engagement metrics (measured with Likes, Shares and Comments) may not always give the correct picture of customer engagement which can be thought based (cognitive) or affect based (emotional).

To academicians, this paper provides a better understanding of the concept of DCM and provides some avenues for further research. The interplay between the characteristics of DCM interaction and its relevance across platforms and content formats need to be analysed and tested. Each of the three FPs generates a specific set of research questions to facilitate the specification and/or refinement of the conceptual domain. The research questions derived from FP1 focus on exploring the fundamental nature and characteristics of DCM. The research questions derived from FP2 focus on the development of digital content and strategies for implementing it. FP3 leads to a deeper understanding of the antecedents of engagement in a DCM interaction.

Despite its contributions, this research also has a few limitations. The study is purely theoretical in nature. Therefore, it renders a need for further (empirical) investigation, testing, and validation of the proposed FPs of DCM. Unlike empirically testable research propositions, our FPs outline DCM's conceptual domain and relationships (similar to Brodie et al. (2011) and Hollebeek \& Macky's (2019) approach). Though we expect these propositions to prove useful to all stakeholders wishing a better understanding of the concept of DCM and its theoretical association, these have to be tested empirically to draw conclusive 
evidence. Some of the areas that can be covered by future research studies are listed in Table 2 .

Table 2: Suggestions for Future Research Avenues Arising from the Three Fundamental Propositions on DCM

\begin{tabular}{|c|c|}
\hline $\begin{array}{l}\text { Fundamental } \\
\text { Proposition }\end{array}$ & Sample Research Questions \\
\hline $\begin{array}{l}\text { FP } 1 \text { : Effective DCM } \\
\text { provides its target } \\
\text { audience digital content } \\
\text { that is valuable, relevant, } \\
\text { reliable, consistent, } \\
\text { interactive and } \\
\text { entertaining }\end{array}$ & $\begin{array}{l}\text { - How can these characteristics be measured? } \\
\text { - Do these characteristics form a continuum, or will it be } \\
\text { mutually exclusive? } \\
\text { - Which one of these characteristics plays the most } \\
\text { significant role in retaining existing and attracting } \\
\text { prospective customers to DCM? } \\
\text { What is the role of these characteristics in generating } \\
\text { brand-related consequences, such as Brand Attitude, Brand } \\
\text { Trust, Brand Equity, Purchase Intention, etc.? }\end{array}$ \\
\hline $\begin{array}{l}\mathbf{F P}_{2} \text { : DCM content } \\
\text { disseminated in different } \\
\text { content formats through } \\
\text { appropriate digital } \\
\text { platforms/channels elicit } \\
\text { the required responses } \\
\text { from the target audience }\end{array}$ & $\begin{array}{l}\text { Which content format(s) is/are most preferred by the target } \\
\text { audience to interact with DCM? } \\
\text { Will these preferences vary across the various } \\
\text { disseminating platforms? } \\
\text { Will the DCM content format and disseminating platform } \\
\text { preferences of target audiences vary with the type of } \\
\text { customer and their respective stages in the buying cycle? } \\
\text { Will there be any moderating effect of content type (e.g. } \\
\text { textual, image/ video-based) or content platform (Firm's } \\
\text { website, blog, social networking site, video-sharing site) } \\
\text { on existing and prospective customer's brand related } \\
\text { responses (e.g.: Brand Attitude, Brand Trust, Brand } \\
\text { Equity, Purchase Intention, etc.) to DCM? }\end{array}$ \\
\hline $\begin{array}{l}\text { FB }_{3} \text { : Appropriately } \\
\text { delivered, gratifying DCM } \\
\text { content is capable of } \\
\text { triggering positive target } \\
\text { audience engagement }\end{array}$ & $\begin{array}{l}\text { What is the effect of the six key characteristics of DCM } \\
\text { (FP1) on the behavioural, emotional, and cognitive } \\
\text { components of engagement respectively? } \\
\text { Will the level of behavioural, emotional, and cognitive } \\
\text { engagement triggered in target audiences differ with the } \\
\text { type of content formats used for DCM interaction? } \\
\text { - Will the different DCM disseminating platforms (such as a } \\
\text { Firm's website, blog, social networking site, video-sharing } \\
\text { sites) generate differing levels of engagement - } \\
\text { behavioural, emotional, and cognitive? }\end{array}$ \\
\hline
\end{tabular}

\section{Conclusion}

Marketing has always been a dynamic and challenging task. With the advancements in technologies and the diminishing interest, patience, and attention span of consumers to push marketing tactics, marketers are forced to look for creative ways to lure consumers. Digital Content Marketing is an obvious solution 
to this problem. Through the creation of interactive, reliable, relevant and valuable digital content, marketers help both existing and prospective consumers to solve their problems. This requires anticipating their informational and entertainment needs and wants. Though this domain of marketing has been growing fast, academic research is still in its nascent stage.

In this paper, we provided a conceptual analysis of DCM using existing literature. From this analysis, three fundamental propositions (FPs) were developed. Such conceptualising and relationship building exercises are important as they lead to the advancement of knowledge in the field (MacInnis, 2011). FP1 explored the characteristics of DCM communications. These characteristics are content value, relevance, reliability, consistency, interactivity, and entertainment. These would help marketers in developing appropriate content for their consumers based on their specific informational or entertainment needs. FP2 explicated the importance of selecting appropriate content formats and content platforms to deliver the desired gratifications through a DCM communication. FP3 explained engagement as the first level brand related consequence of DCM that delivers consumers' desired gratifications through appropriate content formats and platforms. This paper provides a springboard for academicians to understand the interplay between the characteristics of DCM content across platforms and content formats in eliciting positive consumer engagement. As "conceptual advances are critical to the vitality of the marketing discipline" (MacInnis, 2011, p. 136) this paper can be a good starting point for further research on DCM.

\section{Declaration of Conflicting Interests}

The authors declared no potential conflicts of interest with respect to the research, authorship, and publication of this article.

\section{Acknowledgment}

The authors would like to acknowledge the valuable inputs and suggestions of the reviewers of this article.

\section{References}

Al-Gasawneha, J. A., \& Al-Adamat, A. M. (2020). The mediating role of e-word of mouth on the relationship between content marketing and green purchase intention. Management Science Letters, 10, 1701-1708. https://doi.org/10.5267/j.msl.2020.1.010 
Ashley, C., \& Tuten, T. (2014). Creative strategies in social media marketing: An exploratory study of branded social content and consumer engagement. Psychology \& Marketing, 32(1), 15-27. https://doi.org/10.1002/mar.20761

Barari, M., Ross, M., Thaichon, S., \& Surachartkumtonkun, J. (2020). A metaanalysis of customer engagement behaviour. International Journal of Consumer Studies. https://doi.org/10.1111/ijcs.12609

Beard, F., Petrotta, B., \& Dischner, L. (2021), A history of content marketing. Journal of Historical Research in Marketing, 13(2), 139-158. https://doi.org/10.1108/JHRM-10-2020-0052

Behnam, M., Hollebeek, L. D., Clark, M. K., \& Farabi, R. (2021). Exploring customer engagement in the product vs. service context. Journal of Retailing and Consumer Services, 60, 102456. https://doi.org/10.1016/j.jretconser.2021.102456

Bloomstein, M. (2012). Content strategy at work. Elsevier.

Brodie, R. J., Hollebeek, L. D., Jurić, B., \& Ilić, A. (2011). Customer engagement: Conceptual domain, fundamental propositions \& implications for research in service marketing. Journal of Service Research, 14(3), 252-271. https://doi.org/10.1177/1094670511411703

Brodie, R. J., Ilic, A., Juric, B., Hollebeek, L. D., (2013). Consumer engagement in a virtual brand community: An exploratory analysis. Journal of Business Research, 66(1), 105-114. https://doi.org/10.1016/j.intmar.2020.05.001

Bruhn, M., Schoenmueller, V., \& Schäfer, D. B. (2012). Are social media replacing traditional media in terms of brand equity creation? Management Research Review, 35(9), 770-790. https://doi.org/10.1108/01409171211255948

Bu, Y., Parkinson, J., \& Thaichon, P. (2020). Digital content marketing as a catalyst for e-WOM in food tourism. Australasian Marketing Journal (AMJ), 29(2), 142-154. https://doi.org/10.1016/j.ausmj.2020.01.001

Busalim, A. H., Ghabban, F., \& Hussin, A. R. C. (2020). Customer engagement behaviour on social commerce platforms: An empirical study. Technology in Society, 64, 101437. https://doi.org/10.1016/j.techsoc.2020.101437

Castillo, A., Benitez, J., Llorens, J., \& Luo, X. (Robert). (2021). Social mediadriven customer engagement and movie performance: Theory and empirical evidence. Decision Support Systems, 145, 113516. https://doi.org/10.1016/j.dss.2021.113516

Connell, C., Marciniak, R., Carey, L.I. \& McColl, J. (2019). Customer engagement with websites: A transactional retail perspective. European Journal of Marketing, 53(9), 1882-1904. https://doi.org/10.1108/EJM-10-2017-0649

Content Marketing Institute (2014). B2C content marketing (Benchmarks, budgets and trends - North America). Content MarketingInstitute/MarketingProfs 
https://contentmarketinginstitute.com/wpcontent/uploads/2013/10/B2B_Research_2014_CMI.pdf

Cvijikj, I. P., \& Michahelles F. (2011). Monitoring trends on Facebook. Proceedings of Ninth International Conference on Dependable, Autonomic and Secure Computing (pp. 895-902). IEEE. https://doi.org/10.1109/DASC.2011.150

Cvijikj, I. P., \& Michahelles, F. (2013). Online engagement factors on Facebook brand pages. Social Network Analysis and Mining, 3, 843-861. https://doi.org/10.1007/s13278-013-0098-8

Decathlon (2021, March 2). Trekking essentials: Complete list of trekking essentials to pack. Decathlon. https://blog.decathlon.in/articles/things-required-fortrekking\#article-body

Dolan, R., Conduit, J., Fahy, J., \& Goodman, S. (2016). Social media engagement behaviour: A uses and gratifications perspective, Journal of Strategic Marketing, 24(3-4) 261-277. http://dx.doi.org/10.1080/0965254X.2015.1095222

Eigenraam, A., \& Eelen, J., \& Verlegh, P. (2021). Let me entertain you? The importance of authenticity in online customer engagement. Journal of Interactive Marketing. 54. 53-68. https://doi.org/10.1016/j.intmar.2020.11.001

Rancati, E., \& Gordini, N. (2014). Content marketing metrics: Theoretical aspects and empirical evidence. European Scientific Journal, 10(34), 1857-7881. https://eujournal.org/index.php/esj/article/view/4825

Firstcry Parenting (2020). Firstcry parenting. https://parenting.firstcry.com/

Forouzandeh, S., Soltanpanah, H., \& Sheikhahmadi, A. (2014). Content marketing through data mining on Facebook social network. Webology, 11(1), 1-18.

Geng, R., Wang, S., Chen, X., Song, D., \& Yu, J. (2020). Content marketing in ecommerce platforms in the internet celebrity economy. Industrial Management \& Data Systems, 120(3), 464-485. https://doi.org/10.1108/imds-05-2019-0270

Gunelius (2011). Content marketing for dummiers. Wiley.

Halligan, B., \& Shah, D. (2010), Inbound marketing. Wiley.

Herzog, H. (1944). What do we really know about day-time serial listeners? In P. Lazarsfeld \& F. Stanton (Eds.), Radio research 1942-1943 (pp. 3-33). Duel, Sloan and Pearce.

Hollebeek, L. D., Glynn, M. S., \& Brodie, R. J. (2014). Consumer brand engagement in social media: Conceptualization, scale development and validation. Journal of Interactive Marketing, 29(2), 149-165. https://doi.org/10.1016/j.intmar.2013.12.002

Hollebeek, L. D., \& Macky, K. (2019). Digital content marketing's role in fostering consumer engagement, trust, and value: Framework, fundamental propositions, 
and implications. Journal of Interactive Marketing, 45, 27-41.

https://doi.org/10.1016/j.intmar.2018.07.003

Holliman, G., \& Rowley, J. (2014). Business to business digital content marketing: Marketers' perceptions of best practice. Journal of Research in Interactive Marketing, 8(4), 269-293. https://doi.org/10.1108/JRIM-02-2014-0013

Human, G. J., Hirschfelder, B., \& Jel, J. (2018). The effect of content marketing on sponsor favorability. International Journal of Emerging Markets, 13(5), 12331250. https://doi.org/10.1108/IJoEM-06-2017-0215

Hutchins, J., \& Rodriguez, D. X. (2018, February). The soft side of branding: leveraging emotional intelligence. Journal of Business \& Industrial Marketing, 33(1), 117-125. https://doi.org/10.1108/JBIM-02-2017-0053

Islam, J. U., Rahman Z., \& Hollebeek L. D. (2018). Consumer engagement in online brand communities: A solicitation of congruity theory. Internet Research, 28(1), 23-45. https://doi.org/10.1108/IntR-09-2016-0279

Jacob, M., E. (2021). Does content dissemination through Facebook matter for government departments: A study of Kerala Police Departments Facebook page. International Journal of Advanced Research, 9(4), 272-283. http://dx.doi.org/10.21474/IJAR01/12684

Jacob, M., E., \& Johnson, J. (2020). Can digital content marketing (DCM) be used to influence attitude and purchase intention of consumers? In Conference Proceedings 4th International Conference on Marketing, Technology \& Society. Indian Institute of Management Kozhikode.

Järvinen, J., \& Taiminen, H. (2016), Harnessing marketing automation for B2B content marketing. Industrial Marketing Management, 54, 164-175. https://doi.org/10.1016/j.indmarman.2015.07.002

Kang, K., Lu, J., Guo, L., \& Li, W. (2021). The dynamic effect of interactivity on customer engagement behavior through tie strength: Evidence from live streaming commerce platforms. International Journal of Information Management, 56, 102251.

https://doi.org/10.1016/j.ijinfomgt.2020.102251

Kee, A. W. A., \& Yazdanifard, R. (2015). The review of content marketing as a new trend in marketing practices. International Journal of Management, Accounting and Economics, 2(9), 1055-1064. https://www.ijmae.com/article_117711.html

Kilgour, M., Sasser S. L., \& Larke, R. (2015). The social media transformation process: Curating content into strategy. Corporate Communications: An International Journal, 20(3), 326-343. https://doi.org/10.1108/CCIJ-07-20140046 
Kim, D.-H., Spiller, L., \& Hettche, M. (2015). Analyzing media types and content orientations in Facebook for global brands. Journal of Research in Interactive Marketing, 9(1), 4-30. https://doi.org/10.1108/JRIM-05-2014-0023

Koiso-Kanttila, N. (2004). Digital content marketing: A literature synthesis. Journal of Marketing Management, 20(1-2), 45-65.

https://doi.org/10.1362/026725704773041122

Kumar, A. M. (2021, September 24). Explore Hong Kong in under 25k. Make My Trip (2021). https://www.makemytrip.com/tripideas/blog/budget-trip-to-hongkong

Leung, X., Tanford, S., \& Jiang, L. (2017). Is a picture really worth a thousand words? An experiment on hotel Facebook message effectiveness. Journal of Hospitality and Tourism Technology, 8(1), 19-38. http://dx.doi.org/10.1108/JHTT-08-2016-0039

Li, J., Zou, Z., \& Yang, H. (2019): How does "storytelling" influence consumer trust in we media advertorials? An investigation in China. Journal of Global Marketing, 32(5), 319-334. https://doi.org/10.1080/08911762.2018.1562592

Lieb, R. (2012). Content marketing: Think like a publisher-How to use content to market online and in social media. Que Publishing

Lou, C., \& Xie, Q. (2020). Something social, something entertaining? How digital content marketing augments consumer experience and brand loyalty.

International Journal of Advertising, 40(3), 376-402 https://doi.org/10.1080/02650487.2020.1788311

Lou, C., Xie, Q., Feng, Y., \& Kim, W. (2019). Does non-hard-sell content really work? Leveraging the value of branded content marketing in brand building. Journal of Product \& Brand Management, 28(7), 773-786. https://doi.org/10.1108/JPBM-07-2018-1948

Lusch, R., \& Vargo, S., (2009), Service-dominant logic: A guiding framework for inbound marketing. Marketing Review St Gallen, 26(6), 6-10. https://doi.org/10.1007/s11621-009-0094-6

MacInnis, D. (2011), A framework for conceptual contributions in marketing. Journal of Marketing, 75(4), 136-154. https://doi.org/10.1509/jmkg.75.4.136 McGuire, J. (1974). Psychological motives and communication gratification. In J. Blumler \& E. Katz (Eds.), The uses of mass communications (pp. 167-196). Sage.

Müller, J., \& Christandl, F. (2019). Content is king - But who is the king of kings? The effect of content marketing Sponsored content \& user-generated content on brand responses. Computers in Human Behavior, 96, 46-55.

https://doi.org/10.1016/j.chb.2019.02.006 
Naseri, Z., \& Noruzi, A. (2018). Content marketing process model: A metasynthesis of the literature. Webology, 15(1), 8-18.

Patterson, P., Yu, T., \& De Ruyter, K. (2006, December). Understanding customer engagement in services. [Paper presentation]. ANZMAC 2006, Advancing Theory, Maintaining Relevance [online]

Pulizzi, J. (2012, January 4). Coca-Cola Bets the Farm on Content Marketing: Content 2020. Content Marketing Institute. https://contentmarketinginstitute.com/2012/01/coca-cola-content-marketing-20$20 /$

Pulizzi, J. (2014). The rise of storytelling as the new marketing. Publishing Research Quarterly, 28(2), 116-123. https://doi.org/10.1007/s12109-012-92645

Rather, R. A., Hollebeek, L. D., \& Rasoolimanesh, S. M. (2021). First-time versus repeat tourism customer engagement, experience, and value cocreation: An empirical investigation. Journal of Travel Research, Advance online publication. https://doi.org/10.1177/0047287521997572

Rios, R. E., \& Riquelme, H. E. (2010). Sources of brand equity for online companies. Journal of Research in Interactive Marketing, 4(3), 214-240. https://doi.org/10.1108/17505931011070587

Rose, R. (2017). Content marketing framework. https://contentmarketinginstitute.com/wpcontent/uploads/2016/10/CMI_Framework2016-FINAL-REV.pdf

Rose, R., \& Pulizzi, J. (2011). Managing content marketing. CMI books.

Rowley, J. (2008). Understanding digital content marketing. Journal of Marketing Management, 24(5-6), 517-540. https://doi.org/10.1362/026725708X325977

Shin, M., Back, Ki-J. (2019). Effect of cognitive engagement on the development of brand love in a hotel context. Journal of Hospitality \& Tourism Research, 44(2), 328-350. https://doi.org/10.1177/1096348019890055

Seyyedamiri, N., \& Tajrobehkar, L. (2021), Social content marketing, social media and product development process effectiveness in high-tech companies, International Journal of Emerging Markets, 16(1), 75-91. https://doi.org/10.1108/IJOEM-06-2018-0323

Steimle, J. (2014, September 19). What is content marketing. Forbes. https://www.forbes.com/sites/joshsteimle/2014/09/19/what-is-contentmarketing/\#1ea6a61210b9

Świeczak, W. (2012). Content marketing as an important element of marketing strategy of scientific institutions. Transactions of the Institute of Aviation, 226(5), 130-150. 
Taiminen, K., \& Ranaweera, C. (2019). Fostering brand engagement and valueladen trusted $\mathrm{B} 2 \mathrm{~B}$ relationships through digital content marketing: The role of brand's helpfulness. European Journal of Marketing, 53(9), 1759-1781. https://doi.org/10.1108/EJM-10-2017-0794

Van Doorn, J., Lemon, K., E., Mittal, V., Nab, S., Pick, D., Pirner, P., \& Verhoef, P., C. (2010). Customer engagement behavior: Theoretical foundations and research directions. Journal of Service Research, 13(3), 253-266. https://doi.org/10.1177/1094670510375599

Vollero A., \& Palazzo M. (2015), Conceptualizing content marketing: a delphi approach, Mercati \& Competitività, 1(1), 25-44. https://doi.org/10.3280/MC2015-001003

Vivek, S. D., Beatty, S. E., \& Morgan, R. M. (2012). Customer engagement: exploring customer relationships beyond purchase. Journal of Marketing Theory and Practice, 20(2), 122-146. https://doi.org/10.2753/MTP10696679200201

Wang, P., \& McCarthy, B. (2020). What do people "like" on Facebook? Content marketing strategies used by retail bank brands in Australia and Singapore. Australasian Marketing Journal (AMJ), 29(2), 155-176. https://doi.org/10.1016/j.ausmj.2020.04.008

Wang, W.-L., Malthouse, E. C., Calder, B., \& Uzunoglu, E. (2019). B2B content marketing for professional services: In-person versus digital content. Industrial Marketing Management, 81, 160-168.

https://doi.org/10.1016/j.indmarman.2017.11.006

Wani, M. (2020, May 13). How to host a virtual baby shower. Firstcry Parenting. https://parenting.firstcry.com/articles/how-to-host-a-virtual-baby-shower/

$\mathrm{Wu}, \mathrm{X}$., \& Liu, F. (2018). An analysis of the motivation of customer participation value co-creation in the we-nedia: A study based on content marketing. Open Journal of Business and Management, 6(3), 749-760. https://doi.org/10.4236/ojbm.2018.63057

Yaghtin, S., Safarzadeh, H., \& Zand, M. K. (2020). Planning a goal-oriented B2B content marketing strategy. Marketing Intelligence \& Planning, 38(7), 10071020. https://doi.org/10.1108/MIP-11-2019-0559 